\title{
Education, Training, and Recruitment of Special Collections Librarians: An Analysis of Job Advertisements
}

This study surveys special collections job advertisements that are appropriate for recent graduates of LIS programs to determine the positions' core qualifications and duties in relationship to the relatively recent set of core competencies identified by the Rare Book and Manuscripts Section (RBMS) of the Association of College and Research Libraries (ACRL). Rather than tracing the development of the position or identifying changes and trends, the study assembles a composite image of the opportunities available to new graduates, and the qualifications and competencies in demand by employers, over a five-year period. Although this is an exploratory survey, it is hoped that the information presented here will be useful to inform the types of skills and competencies students seek to develop through internships, independent projects, or coursework. ${ }^{1}$

\section{Literature Review}

\section{Education, Training and Recruitment in Special Collections}

The education and hiring of special collections professionals has become a widely discussed issue in the past decade. In her 2004 white paper on special collections recruitment, Alice Schreyer noted: “The demand for special collections personnel with appropriate professional and scholarly qualifications occurs at a time when special collections is being recognized as central to the mission of research libraries and as the skill set required for these positions is expanding."2 These two pressures, along with the projected retirement of many special collections professionals by 2010, were thought to contribute to a pending crisis in the recruitment and training of special collections librarians.

\footnotetext{
1. A preliminary version of this paper was completed as a student project in Michael Laird's course on Rare Books and Special Collections, School of Information, University of Texas at Austin, spring 2010. The author wishes to extend sincere thanks to Mr. Laird for his suggestions, support, and energy in helping her see the project through to publication. She also wishes to acknowledge the many helpful comments and suggestions of the three anonymous reviewers of this article.

2. Alice Shreyer, "Education and Training for Careers in Special Collections: A White Paper Prepared for the Association of Research Libraries Special Collections Task Force," Association of College and Research Libraries (2004), available online at www.arl.org/bm doc/sctf_ed.pdf, 5 [accessed 1 September 2011].
} 
Schreyer's work provided the basis for the Task Force on Core Competencies, which RBMS charged with developing a list of the skills and expertise central to special collections librarianship in 2005. In their introduction to the competencies, the task force reported that members monitored special collections job postings as they appeared on e-mail discussion lists and in print during 2005, but the task force scope did not include a statistical study. ${ }^{3}$ Instead, the task force took a broad view of the profession as a whole, aiming to address professionals at all levels and in all environments. The task force developed a list of sixteen fundamental competencies and eight specializations, each with its own set of competencies: collection development, information technology, management, preservation and conservation, processing and cataloging, promotion and outreach, public service, and teaching and research.

RBMS dedicated its preconference in 2005 to issues surrounding the education, training, and recruitment of special collections librarians, and many of the articles published in the March 2006 issue of RBM mention the multiple skills and abilities necessary to navigate this varied and often highly specialized environment. In an article on education and recruitment, Susan Stekel Rippley summarized the discussion at the RBMS Round Table at ACRL in 2005, reporting that participants identified core skills including "knowledge of descriptive bibliography, reference work with primary sources, and preservation and subject knowledge," in addition to foreign language proficiency. ${ }^{4}$ However, Deirdre Stam, in an article in the same issue of RBM, offered a contrasting viewpoint: "Beyond basic bibliography and an introduction to the standards and institutions of the field, I would be hard-pressed to identify a core set of skills that I consider to be utterly essential for everyone entering the field.... It is more a matter of matching existing skills to opportunities than piling on more skills 'just in case."' agreed, stating that she believed there are some qualifications all special collections librarians must have, as well as some that are unique to specific environments. ${ }^{6}$ Although the ACRL board approved the RBMS Core Competencies in 2008, the question of how those competencies translate into recruitment, especially for entry-level positions, is still open.

\section{Content Analysis of Job Advertisements}

Although researchers have conducted numerous studies of job announcements

3. Task Force on Core Competencies for Special Collections Professionals, "Guidelines: Competencies for Special Collections Professionals," Rare Book and Manuscript Section, Association of College and Research Libraries, available online at www.ala.org/ala/mgrps/divs/acrl/standards/comp4specollect.cfm [accessed 1 September 2011].

4. Susan Stekel Rippley, "The Education and Hiring of Special Collections Librarians: Observations from a Recent Recruit," RBM (Fall 2005): 83.

5. Deirdre Stam, "Bridge that Gap! Education and Special Collections," RBM (Spring 2006): 28.

6. Alice Schreyer, "What's So Special about Special Collections Librarians?" RBM (Spring 2006): $50-51$. 
focusing on various aspects of academic librarianship, no such study has focused exclusively on special collections librarianship. Studies of job advertisements for academic librarians range from general surveys to focused examinations of single qualifications, roles, or environments, and they may either attempt to track changes over a long period or provide a current snapshot of the job market.

Because special collections librarians often work in academic environments, studies that consider a single position type or broader trends within academic librarianship may help to put special collections librarianship in context. ${ }^{7}$ The large-scale study of academic librarian job advertisements undertaken by Beile and Adams in 2000 found an increasing trend toward technological skills. ${ }^{8}$ However, White's study of subject specialist librarians in 1998 found generalized qualifications such as communication skills to be the most commonly cited, although subject specialist positions were more likely than generalist positions to require a subject master's degree. ${ }^{9}$ Bajjaly's 2005 survey of hiring managers in academic libraries found that personal qualities, along with less specialized qualifications, were most valued in the final consideration of a candidate. ${ }^{10}$

Although this study does not attempt to estimate the number of opportunities available to early-career librarians, it is useful to provide a context for the advertisements considered here. Kennan, Willard, and Wilson, in a 2004 survey of Australian job advertisements, found that as little as 12.5 percent of the study population was suitable for entry-level applicants in a given year and observed that a perceived lack of opportunities may deter students from pursuing study in the field at all. ${ }^{11}$ Bajjaly found more promising numbers: nearly a third of the managers he surveyed reported that they were currently hiring for entry-level positions. Reeves and Hahn's recent study of advertisements for entry-level librarian and archivist positions found a year-to-year increase from 2006 to $2009 .{ }^{12}$ Other studies of academic librarian positions in the United States have suggested that around 20 percent of

7. John Shank's 2006 study of job advertisements for instructional design librarians was especially useful in helping to formulate the structure of the research: "The Blended Librarian: A Job Announcement Analysis of the Newly Emerging Position of Instructional Design Librarian," College \& Research Libraries 67 (Nov. 2006): 515-24.

8. Penny M. Beile and Megan M. Adams, "Other Duties as Assigned: Emerging Trends in the Academic Library Job Market,” College \& Research Libraries 61 (July 2000): 336-47.

9. Gary W. White, "Academic Subject Specialist Positions in the United States: A Content Analysis of Announcements from 1990 through 1998," Journal of Academic Librarianship 25 (Summer 1999): 372-82.

10. Stephen T. Bajjaly, "Contemporary Recruitment in Traditional Libraries," Journal of Education for Library and Information Science 46 (Winter 2005): 53-58.

11. Mary Ann Kennan, Patricia Willard, and Concepcion Wilson, "What Do They Want? A Study of Changing Employer Expectations of Information Professionals," Australian Academic \& Research Libraries 37 (Mar. 2006): 17-37.

12. Robert K. Reeves and Trudi Bellardo Hahn, "Job Advertisements for Recent Graduates: Advising, Curriculum, and Job-Seeking Implications," Journal of Education for Library and Information Science, 51/2 (Spring 2010): 103-119. 
academic library positions are suitable for new graduates with no prior professional experience. ${ }^{13}$

\section{Methodology}

Although special collections librarianship is an established field, several of the difficulties Shank notes in his analysis of advertisements for instructional design positions also affect this study. ${ }^{14}$ No standardized terminology exists for special collections job titles, and duties and qualifications are widely variable. Apart from EXLIBRIS-L, an independently maintained e-mail discussion list hosted at the University of Indiana, no centralized resource exists for special collections job postings. It was therefore necessary to employ various strategies and criteria to overcome these challenges and collect the largest possible population of advertisements for survey.

\section{Data Sources}

Advertisements posted between January 1, 2004, and December 31, 2009, were collected from a number of print and electronic sources. College and Research Libraries News (C\&RL News) supplied the nationally advertised positions in print format for this study. Electronic sources proved more troublesome, even though the majority of positions are currently advertised electronically. As Shank noted, expired postings on national job boards such as ALA's JobList and the job board of the Chronicle of Higher Education are not searchable online, posing serious problems for researchers in this area. There also appears to be a growing trend to shorten printed job advertisements by referring the reader to a Web page, which does not persist beyond the position's posting period.

Following Shank's example, 39 special collections jobs were harvested for this study from the archives of the LIBJOBS e-mail discussion list provided by the International Federation of Library Associations (IFLA), and a much smaller number (4) from the higher education Web site Educause.edu. ${ }^{15}$ David Connolly, the administrator of ALA's JobList, supplied archived postings from August 1, 2006, to December 31, 2009 , in response to a request from the author. This data archive yielded a total of 21 relevant advertisements. The archives of e-mail discussion lists may also prove to be a plentiful source of past job advertisements for current and future researchers. However, due to changes in hosting, the archives of EXLIBRIS-L itself are currently unavailable prior to $2006 .{ }^{16}$ Advertisements were collected from this source

13. Beile and Adams, "Other Duties as Assigned," 336-47.

14. Shank, "The Blended Librarian," 517.

15. IFLA LIBJOBS discussion list, http://infoserv.inist.fr/wwsympa.fcgi/info/libjobs; Educause job board, http: / / www.educause.edu/jobs?tid=16500 [accessed 1 September 2011].

16. The archives formerly hosted at http://cool.conservation-us.org/byform/mailing-lists/exlibris / are unavailable. Archives from 2006 to present are currently hosted at https:/ / listserv.indiana.edu/cgibin/wa-iub.exe?A0=exlibris-1. [Accessed 1 September 2011]. 
from 2006 through 2009, for a total of 17 . The remaining 8 postings were collected from the print edition of $C \& R L$ News. In the case of duplicate postings, the most comprehensive version of the advertisement was selected. The total number of advertisements selected was 88 .

\section{Selection Criteria}

Electronic job boards and discussion lists were searched for the term "special collections" appearing anywhere in the text of the job advertisement, and print advertisements were visually scanned for the same keywords. Because most of the sources contained postings for a broad range of positions in academic environments, this search strategy yielded many advertisements for non-special collections positions. It was therefore necessary to narrow the advertisements selected for inclusion in the study based on the following criteria:

\section{SPECIAL COLLECTIONS WORK}

The varied nature of work in special collections admits a wide range of job functions. However, announcements for conservation or preservation professionals and digital/electronic resource librarians were eliminated from this study, as these are distinct fields with their own qualifications and competencies. Positions that were shared between special collections and another library department were included if at least 50 percent of the time was devoted to the special collections department. If an exact percentage was not specified in the advertisement, but roughly half of the description applied to special collections, the advertisements were included.

\section{LIBRARIANSHIP}

Job advertisements for archivists were not included in this study, as the archives profession is distinct from librarianship. ${ }^{17}$ These professions do have a broad area of overlap, however, and, to reflect this reality, advertisements for hybrid positions (such as librarian/archivists) were accepted for this study. Listings for employment with booksellers and auction houses were excluded, placing the emphasis of the study instead on public or private cultural institutions such as libraries, archives, museums, and research centers.

17. While both archivists and special collections librarians work with historical materials, the author sees the archives profession as separate from librarianship for several reasons. The set of ethics and professional principles that guide archivists differ in many fundamental regards from those that inform librarians. Archivists work primarily with records and documents organized at the series level, while special collections and rare book librarians generally work with materials (print or manuscript) at the item level. For an overview, see Society of American Archivists, "So You Want to Be an Archivist: An Overview of the Archives Profession," www2.archivists.org/profession [accessed 1 September 2011]. See also Sara Schmidt, "Split Personalities: A Librarian in the Archives," paper presented at the Society of American Archivists Conference, August 2009, http://www.archivists.org/saagroups/lonearr/publications/Schmidt_SplitPersonalities.doc [accessed 27 September 2011]. 


\section{ENTRY LEVEL}

This criterion was the most difficult to define, as very few job advertisements actually contain the phrase "entry level." For the purposes of this study, positions were considered to be entry level if they required less than one year of post-MLS experience or if the amount of experience required was unspecified. ${ }^{18}$ Advertisements with "Head" or "Director" in the position title were excluded, along with those specifying supervisory duties over other professionals. Positions with supervision over paraprofessional staff, student workers, and graduate interns were included. Although student internships were excluded, paraprofessional positions have been included for consideration.

\section{Preliminary Processing and Coding}

Content analysis of the job advertisements included the following elements:

- Position title

- Duties/responsibilities

- Required education and training

- Preferred education and training

- Required competencies, experience, and skills

- Preferred competencies, experience, and skills

- Institution type

- Salary

- Job status (professional, faculty, tenure track, and the like)

- Geographic location

Using a spreadsheet in Google documents with an associated Web form, a preliminary pass was made through the population of advertisements to break the data into sections for duties, required qualifications, and desired qualifications. The text of online advertisements was pasted into the appropriate sections; print advertisements were retyped. At this stage, information about degree requirements, length of experience, salary, position status, geographical area, posting date, and institution type were coded by hand directly from the position announcements.

After accomplishing this preliminary coding, the Simple Concordance Program (SCP) text analysis software developed by Alan Reed was used to create a keyword index of the document sections. ${ }^{19}$ The software created a list of all words appearing in the job advertisements and their frequencies. Modeling the analysis after the categorization tree Kennan, Willard, and Wilson used in their review of Australian job advertisements, the author used this word list to develop a vocabulary of keywords

18. This criteria is similar to that followed by Reeves and Hahn, "Job Advertisements for Recent Graduates," 107.

19. Simple Concordance Program is available for download at www.textworld.com/scp/ [accessed 1 September 2011]. 


\begin{tabular}{|c|c|}
\hline Category & Keywords \\
\hline Technology & $\begin{array}{l}\text { automated, automation, computer, computers, database, } \\
\text { databases, digital, digitization, digitizing, electronic, } \\
\text { hardware, machine, microcomputers, software, } \\
\text { technological, technologies, technology, Web, Web page, } \\
\text { Web site, Web sites }\end{array}$ \\
\hline $\begin{array}{l}\text { Reference \& } \\
\text { Public Service }\end{array}$ & $\begin{array}{l}\text { clientele, customer, reference, searching, serving, user, } \\
\text { users, uses, visitors }\end{array}$ \\
\hline Management & $\begin{array}{l}\text { administer, administration, administrative, grant, lead, } \\
\text { leadership, manage, management, manager, manages, } \\
\text { managing, supervise, supervises, supervising, } \\
\text { supervisory }\end{array}$ \\
\hline $\begin{array}{l}\text { Collection } \\
\text { Development }\end{array}$ & $\begin{array}{l}\text { acquire, acquired, acquiring, acquisition, acquisitions, } \\
\text { book trade, collect, collecting, collectors, dealers, donor, } \\
\text { donors, fund, funding, funds, gifts }\end{array}$ \\
\hline $\begin{array}{l}\text { Promotion and } \\
\text { Outreach }\end{array}$ & $\begin{array}{l}\text { communities, community, conferences, exhibit, exhibition, } \\
\text { exhibitions, exhibits, faculty, lectures, organizations, } \\
\text { outreach, present, presentation, presentations, } \\
\text { presenting, program, programming, programs, seminars, } \\
\text { students, undergraduate, undergraduates, workshops }\end{array}$ \\
\hline Technical Services & $\begin{array}{l}\text { aacr, amremm, anglo, anglo-american, catalog, } \\
\text { cataloging, cataloguing, classification, classifications, } \\
\text { control, dacs, dcrb, dcrm, ead, finding, ils, innopac, lcsh, } \\
\text { metadata, millennium, oclc, process, processing, rlin, } \\
\text { voyager }\end{array}$ \\
\hline $\begin{array}{l}\text { Preservation and } \\
\text { Conservation }\end{array}$ & conservation, handling, preservation \\
\hline $\begin{array}{l}\text { Teaching and } \\
\text { Research }\end{array}$ & $\begin{array}{l}\text { historical, history, instruction, instructional, methodology, } \\
\text { publication, publications, published, publishing, research } \\
\text { ability/experience/skills, researching, scholar, scholarly, } \\
\text { scholars, scholarship, teacher, teaching }\end{array}$ \\
\hline
\end{tabular}

classified according to the RBMS Core Competencies. ${ }^{20}$ This framework is included in table 1, and it is the basis for analysis of the required and preferred skills and qualifications sections, as well as the duties sections of the job advertisements.

\section{Findings}

\section{Position Titles}

Four main functional titles emerged from the study population (see figure 1). Position titles could include more than one function (as in the case of librarian/archivist positions). The most common title was Librarian (64.77\%), followed by Curator (15.91\%), and Archivist (14.77\%). Positions with some form of the word catalog in the title made up 17.05 percent.

20. Kennan, Willard, and Wilson, "What Do They Want?" 36-37. 


\section{Figure 1. Position Advertisements by Title}

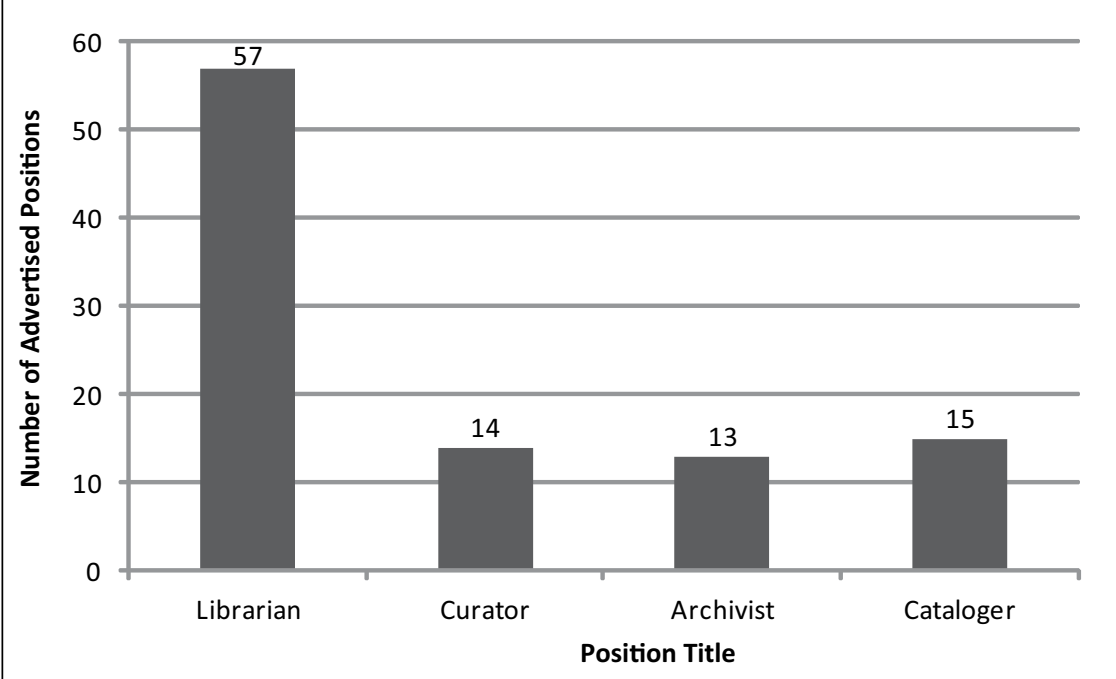

Figure 2. Position Advertisements by Institution Type

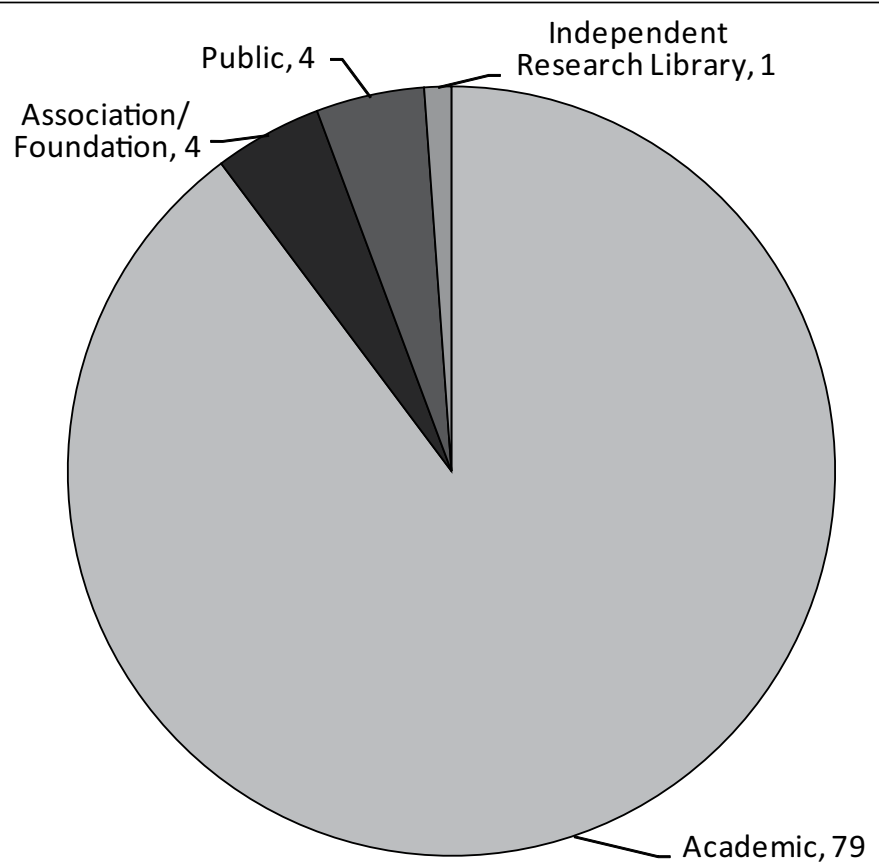

\section{Institution Type}

A majority $(89.77 \%)$ of the positions analyzed were in college or university libraries, with the remaining 10.23 percent divided among public libraries, foundations, independent research libraries, and other types of institutions (see figure 2). 


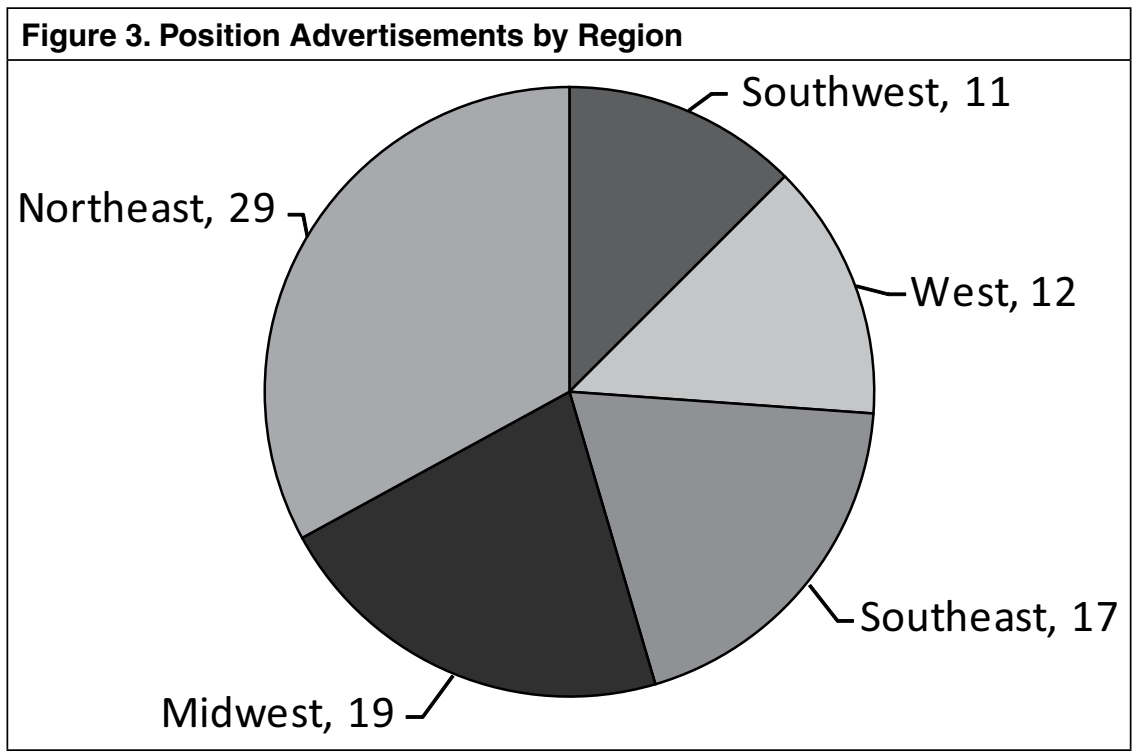

\section{Geographic Distribution}

The state was recorded for each position listing, and results were broken into rough geographic areas (see figure 3). A total of twenty-nine positions (32.95\%) were in the Northeast. The Midwest had the second highest number of positions, with nineteen (21.59\%). Seventeen positions (19.32\%) were in the Southeast, and twelve were in the West (13.63\%). The remaining eleven positions (12.50\%) were in the Southwest. ${ }^{21}$

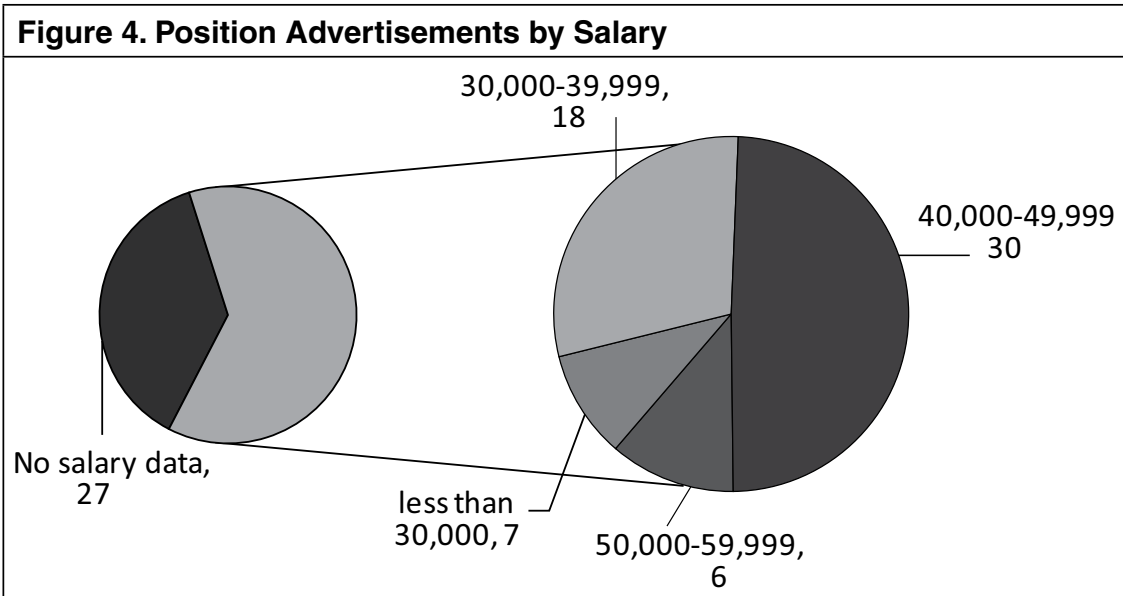

21. Regions were defined as follows from states that appeared in the study population. Northeast: Connecticut, Washington, D.C., Delaware, Massachusetts, Maryland, New Jersey, New York, Pennsylvania, Rhode Island, Vermont. Midwest: Illinois, Indiana, Kansas, Michigan, Minnesota, Missouri, Ohio. Southeast: Alabama, Georgia, Kentucky, Louisiana, Mississippi, North Carolina, Tennessee, Virginia. West: California, Idaho, South Dakota, Utah. Southwest: Arizona, New Mexico, Oklahoma, Texas. 


\section{Salary}

Salary information was listed in $61(69.32 \%)$ of the job advertisements (see figure 4). Only the minimum salary ranges were recorded for each position, although several were listed at multiple ranges depending on qualifications and experience. Part-time and hourly salaries were calculated to full-time equivalents. The lowest salary recorded was $\$ 25,000$, and the highest was $\$ 57,500$, with an average salary of $\$ 39,788$, and a median of $\$ 40,000$.

\section{Figure 5. Position Advertisements by Position Status}

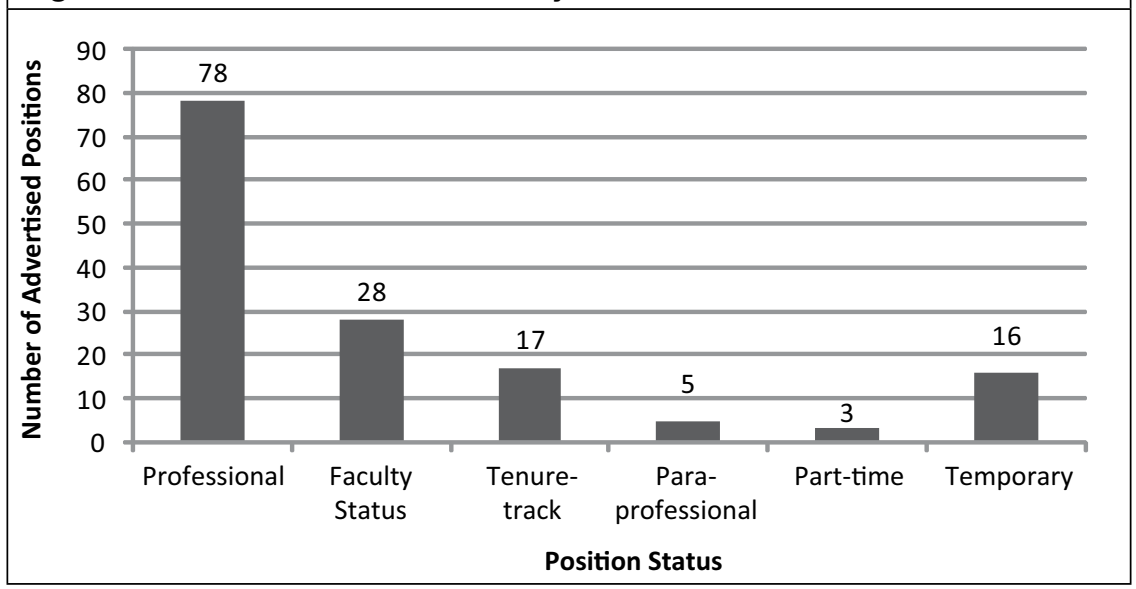

\section{Position Status}

In 95.45 percent of the advertisements, the hiring institution indicated whether the position was considered professional within its own organizational structure (see figure 5). Most of the positions in the study population were considered to be professional (88.64\%), but a small number (5.68\%) were designated as paraprofessional positions.

About one-third of the positions (31.82\%) conferred faculty status; 19.32 percent of the entire population was considered to be tenure track. Almost as many (18.18\%) were temporary, time-limited positions, and a very small percentage (3.41\%) were part-time.

\section{Degree Requirements and Preferences}

Specific educational degree requirements were mentioned in 97.72 percent of the advertisements (see figure 6). A single master's degree was enough to meet the required qualifications for employment in 76.14 percent of the study population. The MLS was the only degree required in 51.14 percent, and another 25.00 percent specified either the MLS or a master's degree in a relevant subject area. Interestingly, 5.68 percent of positions required only a specialized bachelor's degree, and the same percentage required a specialized bachelor's degree in addition to the MLS. A second master's degree was required in 7.95 percent of the advertisements, and 


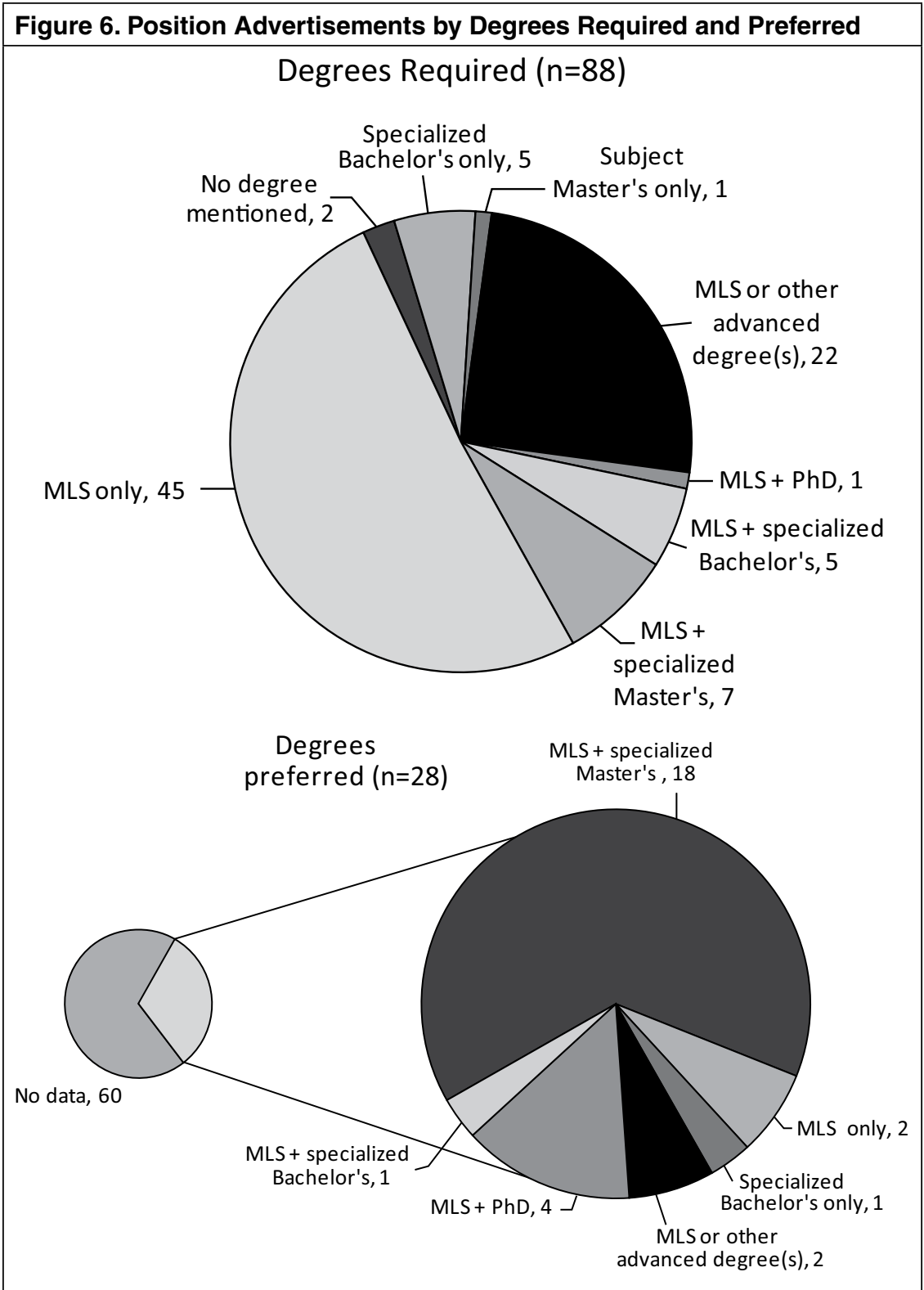

a Ph.D. was required in 1.14 percent. The same percentage (1.14\%) required only a master's degree in a subject area related to the collections.

Only 28 of the advertisements, or 31.82 percent of the study population, included information about preferred degree qualifications. Of these, 82.14 percent called for a specialized advanced degree in addition to the MLS, and 14.29 percent specified that the Ph.D. was preferred. These represent 26.14 percent and 4.55 percent of the population as a whole, respectively. 
A textual analysis was performed on the required and preferred qualifications sections to look for specialized education and training mentioned in conjunction with degree requirements. Surprisingly, the most commonly required specialization was in archives or archival science; this keyword appeared in 37.50 percent of the advertisements as a required qualification and was either required or preferred in 63.63 percent. A degree, coursework, or demonstrated knowledge of history was the second most common educational specialization (38.63\% required, $43.18 \%$ required or preferred). Specialization in rare books was the third most frequent $(23.86 \%$ required, $32.95 \%$ required or preferred); the term bibliography, in its historical sense, appeared in only one advertisement. Reading or bibliographic knowledge of foreign languages was also important (19.32\% required, $38.36 \%$ required or preferred).

\section{Required and Preferred Length of Experience}

A specific length of experience was either not mentioned or specifically stated as not required in 48.86 percent of the population (see figure 7). Two advertisements $(2.27 \%)$ required $1-5$ years of experience, pre- or post-MLS. The remaining advertisements $(48.86 \%)$ required experience but did not specify how much or whether preprofessional experience was acceptable.

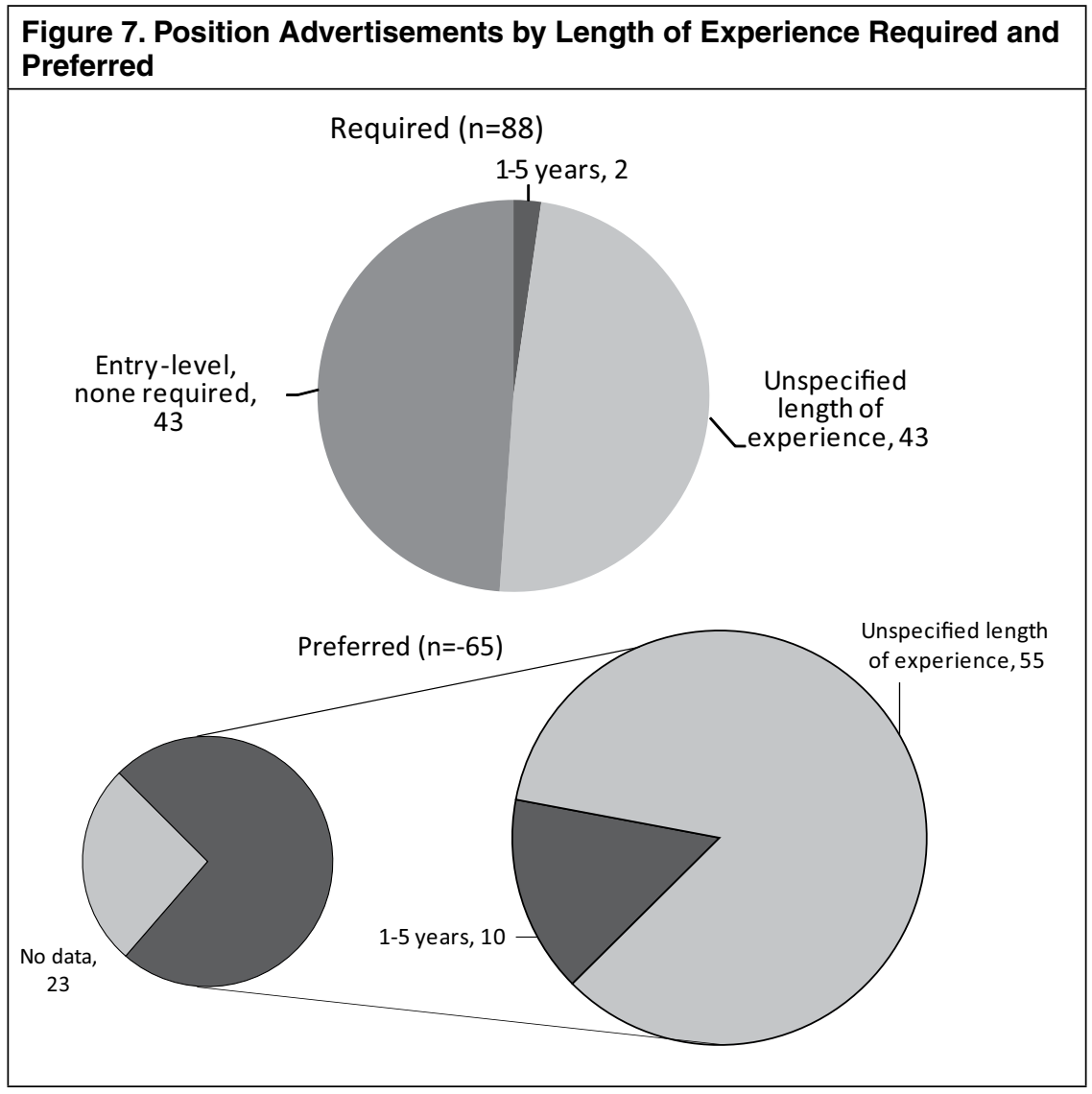


Of the 88 advertisements in the study population, 73.86 percent included a preferred length of experience. A large majority of these stated an unspecified amount and type of experience as preferred ( $84.62 \%$, or $62.50 \%$ of the entire population). The remaining 15.38 percent specified that $1-5$ years of experience was preferred (11.36\% of the entire population).

Nine positions were listed at open rank, meaning that hiring institutions placed entry-level candidates into consideration for the advertised position alongside more experienced professionals.

\section{Required and Preferred Skills and Qualifications}

Because not all advertisements listed preferred qualifications, requirements were first analyzed separately, and then required and preferred qualifications were analyzed together (see figure 8). As mentioned above, the classified vocabulary of terms created using SCP and the RBMS Competencies informs the analysis in this section. Individual keyword searches were run in SCP, and the number of advertisements containing the keywords was noted (see appendix).

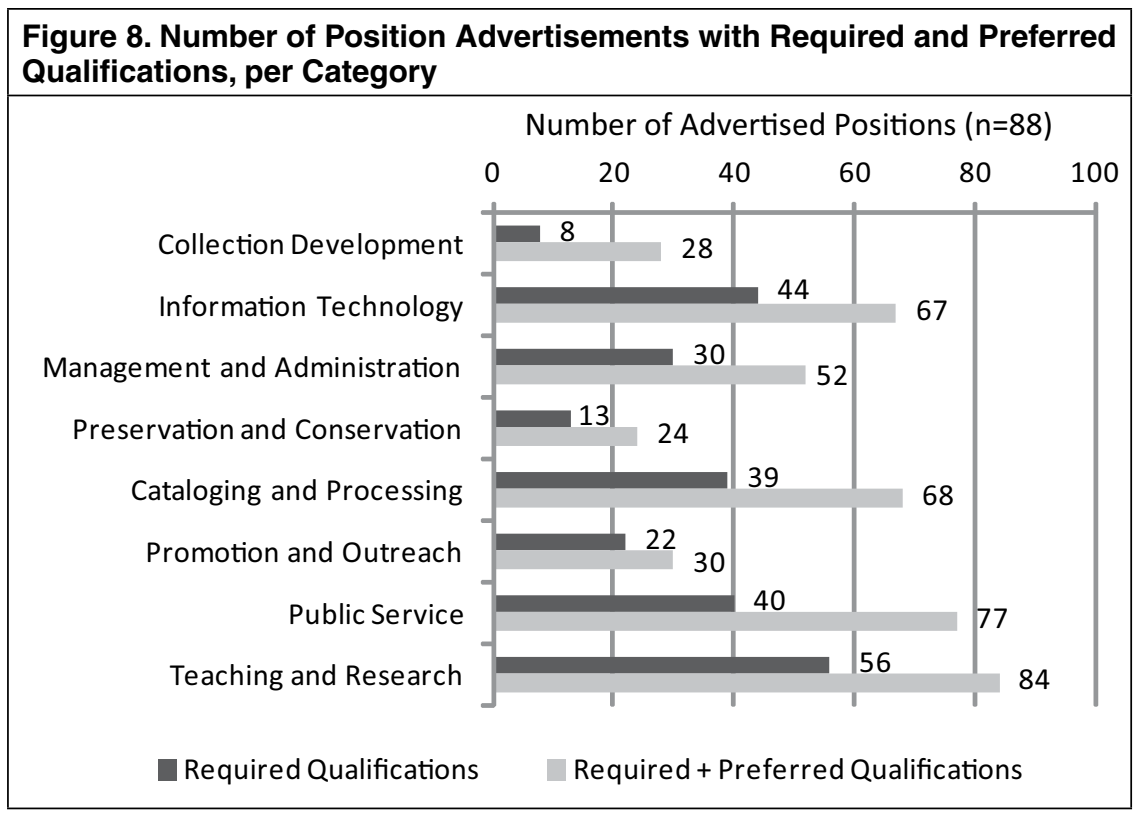

Specific required qualifications varied widely. The single most common keyword in the required qualification sections was knowledge or education in history (31.82\%), followed by cataloging (28.41\%). Generalized technological skills were also important (23.86\%), and management, public services, and research experience each appeared in over one-fifth of the advertisements (each at about $21.59 \%$ ). 
Many of the advertisements specified that candidates should have excellent communication, organizational, and interpersonal skills (64.77\%, 30.68\%, and $45.45 \%$, respectively).

Analyzing the required and preferred qualifications together confirmed the demand for historical knowledge, cataloging, and technological skills. Positions requiring or preferring general cataloging skills made up 44.32 percent of the survey population. Historical knowledge was represented in 43.18 percent, and technology skills were called for in 31.82 percent. However, several competencies gained considerably in the addition of preferred qualifications to the analysis: public services experience $(21.59 \%$ required, $60.23 \%$ required or preferred); research skills or experience $(21.59 \%$ required, $40.91 \%$ required or preferred); and teaching experience or skill (5.68\% required, $23.86 \%$ required or preferred).

Because the single qualification keywords were so variable, it was more useful to analyze them at the category level. Based on aggregate keyword searches, three competency categories each appeared in the qualifications of over 75 percent of the study population. The categories with the most keyword matches were those related to Research and Teaching (63.64\% required, $95.45 \%$ required or preferred), Public Service (45.45\% required, $87.50 \%$ required or preferred), Cataloging and Processing (44.32\% required, $77.27 \%$ required or preferred), and Information Technology ( $50.00 \%$ required, $76.14 \%$ required or preferred). The category Management and Administration (34.09\% required, 59.09\% required or preferred) was the next most common.

\section{Figure 9. Number of Position Advertisements with Duties per Category}

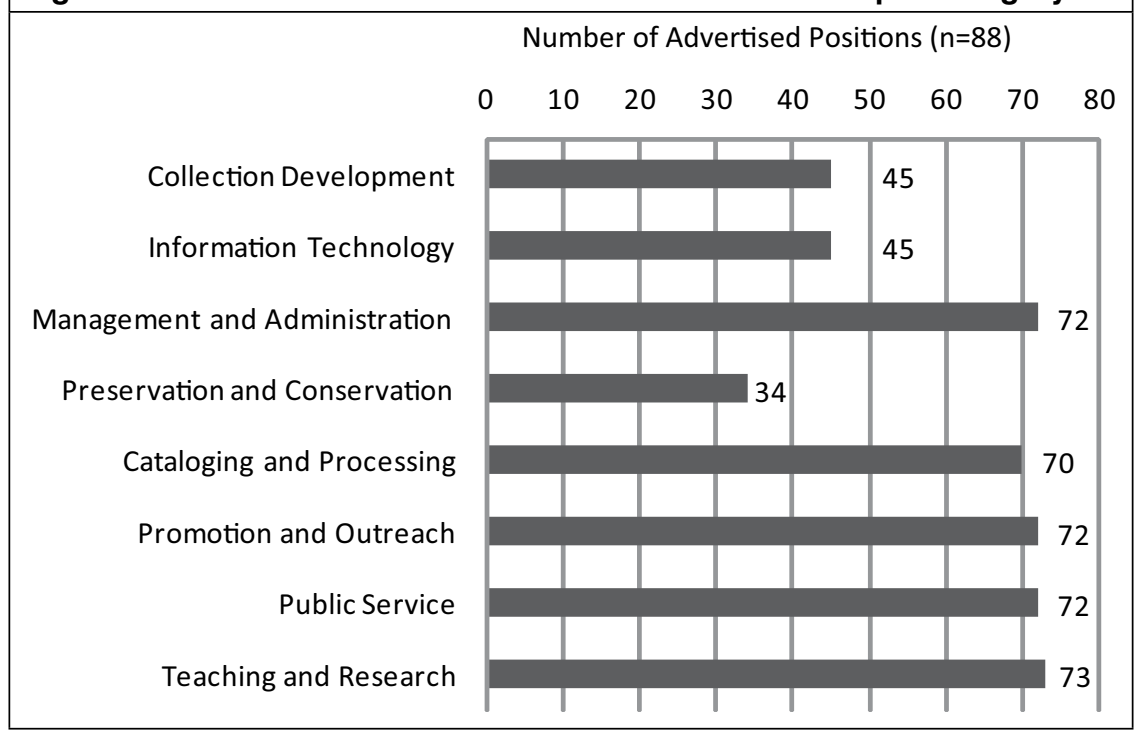




\section{Duties and Responsibilities}

The duties and responsibilities sections of the job advertisements were analyzed using SCP and the same set of keywords developed for the required and preferred qualifications (see appendix). The data in this section fell into several highly cited keywords, most of which grouped around the halfway mark ( $45 \%-55 \%$; see figure 9 ). The most frequently occurring single keyword was reference (68.18\%), followed by research ( $55.68 \%)$. Supervisory duties were included in 48.86 percent of advertisements, and cataloging duties appeared in 47.73 percent. Management and programming duties were cited in 46.59 percent of advertisements.

As with the qualifications section, analyzing this section by category provided more meaningful results. The most cited category was Teaching and Research (82.95\%). The categories Promotion and Outreach, Public Service, and Management and Administration each appeared in 81.82 percent of advertisements. The Cataloging and Processing category, as in the required and preferred qualifications, was represented in a large number of position advertisements as well (79.55\%).

\section{Discussion}

Although the analysis of job advertisements is limited in nature, the findings detailed above suggest several conclusions about the nature of entry-level employment in special collections and about the place and nature of special collections work within the context of academic librarianship in general.

\section{Entry-Level Considerations}

This study does not purport to provide conclusive evidence about the number of available entry-level special collections positions relative to the overall number of advertised positions in the field. However, the fact that only 88 nationally advertised entry-level positions could be located for a period of six years indicates that such jobs are scarce, even taking into account previously discussed difficulties in locating the full text of past advertisements. If the 88 positions here represent the majority of those actually available during the period of study (2004-2009), a reasonable estimate of the number of professional, nationally advertised entry-level positions in special collections environments each year is around twenty, perhaps fewer.

At face value, the data from these advertisements suggest that most special collections positions may be attainable to candidates who only possess an MLS or, to a lesser extent, a subject master's degree. However, advertisements in over 30 percent of the study population specified a preference for an advanced degree in addition to the MLS. Taken together with the scarcity of available positions, this preference may mean that candidates possessing only the MLS may have a somewhat reduced chance of success on the job market. Despite recent discussion about recruiting 
and training candidates with doctoral degrees to fill perceived gaps in the available pool of candidates, employers do not seem to expect this qualification, at least at entry level. Even so, the data on education point to a highly competitive and specialized field in which candidates may need additional education in a relevant subject area for the greatest chance of success.

The data pertaining to experience reinforce this image of the entry-level job market. Very few of the positions were advertised using the phrases "entry level," "Librarian I," or other cues that indicated an entry point into the profession. Only half of advertisements specified no experience, and a majority preferred applicants to have at least some experience in various areas. This finding suggests that internships and other forms of student work are critical for developing an appropriate set of experiences and skills. The wide variety of skill sets in demand, ranging from cataloging to reference, suggests that prospective special collections librarians should avoid overspecialization within the field of library and information science; instead, they should take care to cultivate as broad a range of experiences as possible, including work in both technical services and public services environments.

Further evidence suggests that professional experience may be necessary even in situations in which a position is ostensibly entry level. Nine positions were listed at open rank, generally ranging from entry level to a rank requiring more than five years of experience. Hiring institutions assigned rank to the selected candidate upon employment, based on qualifications and experience. Although this means that entry-level candidates technically were eligible to apply for these positions, these hiring practices place them in direct competition with senior professionals.

\section{The Boundaries of the Profession}

Although the author's selection criteria for advertisements eliminated postings for archivists from consideration, an additional scan of the job advertisements revealed a number of duties and qualifications related to work in archives. Further textual analysis revealed that 63.64 percent of the job advertisements included some form of the word archives in the required and preferred qualifications, including specialization in archival science, experience with archival processing, or familiarity with archival principles. Although hybrid librarian/archivist positions were included in the study population, the term Archivist appeared in less than 15 percent of position titles. This discrepancy between job titles and qualifications suggests that institutions may be blurring the boundaries between librarianship and the archives profession, seeking an archivist's approach to historical materials under the title of Librarian.

This finding reflects larger trends within librarianship and its allied professions in archives and museums. Although professionals in all three fields have long recog- 
nized the commonalities among cultural institutions, the last decade has seen a decided increase in the discussion and implementation of collaborative projects. Shared challenges, including changing user expectations, increased financial pressures, and new opportunities introduced by the digital environment, have led some to theorize that these types of institutions may best serve their missions by working together and may in fact be on a path toward institutional convergence. ${ }^{22}$ RBMS dedicated its 2006 preconference to issues of convergence, ${ }^{23}$ and OCLC Research has also sponsored research, training, and conferences on this issue. ${ }^{24}$ Schreyer touches on convergence between special collections libraries and archives in her white paper, writing that "Archivists, in particular, have skills that are increasingly essential in special collections, and efforts must be made to bridge the cultural divide that too often separates archivists and librarians." ${ }^{25}$

For the purposes of this study, the findings suggest that William Landis's persona of the 21st-century special collections librarian, a professional who gets her start as an archival processor on a hidden collections grant, may indeed be a portrait of the next generation of special collections librarians. ${ }^{26}$ Although this study is too limited to draw definite conclusions about the entire field, the general discussion about convergence within the profession, paired with the appearance of archives-related job functions in librarian job advertisements, suggest that aspiring rare book and special collections librarians may do well to seek out basic training in the skills and principles of archival work in addition to library training. Early-career special collections librarians may also gain a broad educational base and entry into the profession through education, training, and work experience in archival environments.

\section{General vs. Specialized}

As in White's study of academic subject specialists, special collections job advertisements contain a mixture of general and highly specialized qualifications and duties. The advertisements in this study reveal a picture of the profession in which generalized library skills_cataloging, reference, and research support—are applied in a specialized environment. Reference and research were the most common keywords

22. Diane Zorich, Guter Waibel, and Ricky Erway, "Beyond the Silos of the LAMs: Collaboration among Libraries, Archives and Museums," Report produced by OCLC Research, 2008. Available online at www.oclc.org/research/publications/library/2008/2008-05.pdf, 10-12 [accessed 1 September 2011].

23. Association of College and Research Libraries, Rare Books and Manuscripts Section, "Libraries, Archives and Museums in the Twenty-First Century: Intersecting Missions, Converging Futures?" program online at www.rbms.info/conferences/preconferences/2006/index.html [accessed 1 September 2011]; proceedings published in RBM, May 2007.

24. An overview of RLG/OCLC Research activities on this topic is available at Online Computer Library Center, "Library, Archive and Museum Collaboration," available online at www.oclc.org/research/activities/lamsurvey/default.htm [accessed 1 September 2011].

25. Schreyer, "Education and Training for Careers in Special Collections," 5.

26. William E. Landis, "Personas and Archetypes: Envisioning the 21st-Century Special Collections Professional,” RBM 7 (Spring 2006): 40-48. 
cited in the duties section. A scan of the keywords in context revealed that most of these references dealt with work applicable to a research library environment in general, referring to the principles and practices of research librarianship, assisting researchers, and understanding the research process. Job advertisements also cited generalized computer and information technology skills frequently. The presence of these keywords in the study population corresponds to the general rise in technological expertise among academic librarian positions.

Knowledge and skills pertaining to generalized library cataloging were also among the most common keywords in both the qualifications and duties sections. Around 69 percent of the positions had a cataloging or processing component. These data may reflect the push to catalog hidden collections, and part of the study population may consist of new positions made possible through grant funding for this purpose. Either way, the data suggest that a solid knowledge of the systems and standards of library cataloging and archival arrangement and description would be beneficial to job seekers in this area.

Although generalized skills were most prevalent, specialized subject knowledge was one of the most cited qualifications in the study population. Knowledge of history pertinent to individual institutions' collections appeared in both the qualifications and duties sections. Analysis of the position duties and responsibilities sections reflects a strong need for the ability to apply this knowledge in a wide variety of tasks, including teaching, research, and research assistance. Position listings also call for the same types of specialized knowledge to be applied in generalized cataloging, outreach, and instruction tasks. Reading knowledge of foreign languages, represented in almost 40 percent of the required and preferred qualifications, probably also relates to the individual needs of the hiring institutions and their collections.

Even so, the data suggest a possible gap between the qualifications that hiring institutions look for in entry-level candidates and the types of duties the selected candidate will be expected to carry out. For most of the categories, the numbers for the required and preferred qualifications sections (analyzed together) and the duties sections were very closely aligned. However, two of the categories appeared in relatively few of the qualifications sections, but they were well represented among the duties sections. The Promotion and Outreach category had the largest discrepancy of this type, appearing in 81.82 percent of the duties sections, but only in 25.00 percent of the required qualifications and 34.09 percent of the required and preferred qualifications. Similarly, the Management and Administration category also appeared in 81.82 percent of the duties sections but was only mentioned in 34.09 percent of the required qualifications and 59.09 percent of the required 
and preferred qualifications. This may indicate that hiring institutions need staff to carry out these job functions, but they are willing to allow applicants to develop the necessary skills and competencies on the job. In the case of management and administrative functions, this makes sense, as this survey examines entry-level positions for which candidates are unlikely to have previous management experience. However, it is unclear why hiring institutions would not expect experience or coursework applicable to job functions in the Promotion and Outreach section. The reverse situation was found in the Information Technology category; institutions specified qualifications in 76.13 percent of the required and preferred sections but only included associated duties in 51.14 percent of the advertisements. Such duties may be so routine as to bear no mention, or institutions may desire staff members who are technologically up-to-date regardless of their job duties.

As Stam suggested in her 2006 article, finding employment in special collections may be a matter of matching existing skills to existing needs. However, as Schreyer also pointed out, a broad base in traditional library service areas is still needed. The data suggest that students or early-career professionals may need to combine highly specialized education or subject knowledge with comprehensive experience or training in the fundamentals of library service, including reference, cataloging, and research skills.

\section{Directions for Future Research}

This exploratory survey uncovered a number of issues that apply to the education and hiring of special collections librarians, but further work is needed to understand the relationships among special collections librarianship and related fields. For example, future research could determine whether the archives-related job functions found in librarian job advertisements in this study are a result of budget restrictions (combining vacant librarian and archivist positions to save resources), a trend to combine special collections and archives departments, a change in collecting practices within special collections and rare book libraries, or, perhaps, longstanding tradition in the profession.

Further work is also needed to overcome the limitations imposed by this study's short time frame and focus on entry-level positions. A larger-scale study of position postings over a longer period of time would uncover broader issues and trends across all levels of the profession, and a census of all available position postings would enable researchers to estimate the percentage of positions at various levels.

Research on job advertisements can reveal only a small portion of the overall picture of the field; thus, a complete view of recruitment and hiring in the profession cannot be gained without the addition of other types of research. Advertisements 
for some positions may call for qualifications so specialized they are only applicable at the hiring institution, and this may skew the overall picture of qualifications currently in demand. It is also possible that positions advertised and included in this study were not filled or that they were filled in a different capacity. It would therefore be useful to survey hiring institutions for outcomes to find how closely the qualifications of successful candidates matched those required in the advertised job description. Although studies of job advertisements can provide a useful snapshot, they should be supplemented by multifaceted surveys of hiring managers, educators, and individual special collections librarians, similar to the work done in the archives profession by the $A^{\star}$ CENSUS project. ${ }^{27}$

Schreyer posed an interesting set of questions in her 2006 article in RBM: "How can we recruit individuals with appropriate backgrounds and prepare them, as well as develop those already in the profession, for new roles and responsibilities? What can be done to increase diversity? Is an MLIS degree needed? An advanced subject degree? Both? Is the answer the same for all positions, or for all institutions?"28 Schreyer's questions could form an important basis for future research, yielding quantifiable data on the expectations and preferences of institutions hiring for special collections positions. Further rigorous, detailed, and analytical examinations of these issues would serve the profession well, providing needed guidance to all parties involved in the recruitment and hiring process.

27. Society of American Archivists, "Archival Census and Education Needs Survey in the United States," available online at www.archivists.org/a-census / [Accessed 1 September 2011].

28. Schreyer, "What's So Special about Special Collections Librarians?" 50-51. 


\begin{tabular}{|c|c|c|c|c|c|c|c|}
\hline \multicolumn{8}{|c|}{$\begin{array}{l}\text { Appendix: Counts and Percentages of Position Advertisements for all } \\
\text { Keywords }\end{array}$} \\
\hline \multirow[t]{2}{*}{ Category } & \multirow[t]{2}{*}{ Keyword } & \multicolumn{2}{|c|}{ Required } & \multicolumn{2}{|c|}{$\begin{array}{c}\text { Required + } \\
\text { Preferred }\end{array}$} & \multicolumn{2}{|c|}{ Duties } \\
\hline & & \# ads & $\%$ ads & \# ads & $\%$ ads & $\#$ ads & $\%$ ads \\
\hline \multirow{7}{*}{$\begin{array}{l}\text { Collection } \\
\text { Development }\end{array}$} & Acquire/Acquisitions & 1 & $1.14 \%$ & 3 & $3.41 \%$ & 21 & $23.86 \%$ \\
\hline & Donor(s) & 4 & $4.55 \%$ & 8 & $9.09 \%$ & 16 & $18.18 \%$ \\
\hline & Book trade/dealers & 2 & $2.27 \%$ & 6 & $6.82 \%$ & 6 & $6.82 \%$ \\
\hline & $\begin{array}{l}\text { Funding/fund- } \\
\text { raising }\end{array}$ & 0 & $0.00 \%$ & 5 & $5.68 \%$ & 10 & $11.36 \%$ \\
\hline & Collecting/collectors & 3 & $3.41 \%$ & 4 & $4.55 \%$ & 4 & $4.55 \%$ \\
\hline & $\begin{array}{l}\text { Collection } \\
\text { Development }\end{array}$ & 2 & $2.27 \%$ & 13 & $14.77 \%$ & 27 & $30.68 \%$ \\
\hline & Overall & 8 & $9.09 \%$ & 28 & $31.82 \%$ & 45 & $51.14 \%$ \\
\hline \multirow[t]{8}{*}{$\begin{array}{l}\text { Information } \\
\text { Technology }\end{array}$} & $\begin{array}{l}\text { Automated, } \\
\text { automate, } \\
\text { automation }\end{array}$ & 5 & $5.68 \%$ & 6 & $6.82 \%$ & 1 & $1.14 \%$ \\
\hline & Computer skills & 16 & $18.18 \%$ & 22 & $25.00 \%$ & 1 & $1.14 \%$ \\
\hline & Digital/digitization & 12 & $13.64 \%$ & 24 & $27.27 \%$ & 28 & $31.82 \%$ \\
\hline & Electronic & 5 & $5.68 \%$ & 9 & $10.23 \%$ & 8 & $9.09 \%$ \\
\hline & Software/hardware & 10 & $11.36 \%$ & 16 & $18.18 \%$ & 1 & $1.14 \%$ \\
\hline & $\begin{array}{l}\text { Technology/ } \\
\text { technologies, } \\
\text { technological }\end{array}$ & 21 & $23.86 \%$ & 28 & $31.82 \%$ & 6 & $6.82 \%$ \\
\hline & Web/website & 10 & $11.36 \%$ & 21 & $23.86 \%$ & 22 & $25.00 \%$ \\
\hline & Overall & 44 & $50.00 \%$ & 67 & $76.14 \%$ & 45 & $51.14 \%$ \\
\hline \multirow{6}{*}{$\begin{array}{l}\text { Management } \\
\text { and } \\
\text { Administration }\end{array}$} & $\begin{array}{l}\text { Administration/ } \\
\text { administrative }\end{array}$ & 6 & $6.82 \%$ & 8 & $9.09 \%$ & 10 & $11.36 \%$ \\
\hline & Grant(s) & 0 & $0.00 \%$ & 7 & $7.95 \%$ & 7 & $7.95 \%$ \\
\hline & Leadership & 3 & $3.41 \%$ & 5 & $5.68 \%$ & 5 & $5.68 \%$ \\
\hline & $\begin{array}{l}\text { Manage/ } \\
\text { management }\end{array}$ & 19 & $21.59 \%$ & 27 & $30.68 \%$ & 41 & $46.59 \%$ \\
\hline & $\begin{array}{l}\text { Supervise/ } \\
\text { supervising/ } \\
\text { supervisory }\end{array}$ & 12 & $13.64 \%$ & 23 & $26.14 \%$ & 43 & $48.86 \%$ \\
\hline & Overall & 30 & $34.09 \%$ & 52 & $59.09 \%$ & 72 & $81.82 \%$ \\
\hline \multirow{6}{*}{$\begin{array}{l}\text { Preservation } \\
\text { and } \\
\text { Conservation }\end{array}$} & Conservation & 9 & $10.23 \%$ & 12 & $13.64 \%$ & 8 & $9.09 \%$ \\
\hline & Handling & 2 & $2.27 \%$ & 2 & $2.27 \%$ & 2 & $2.27 \%$ \\
\hline & Housing & 0 & $0.00 \%$ & 0 & $0.00 \%$ & 1 & $1.14 \%$ \\
\hline & Preservation & 7 & $7.95 \%$ & 17 & $19.32 \%$ & 26 & $29.55 \%$ \\
\hline & Treatment & 0 & $0.00 \%$ & 0 & $0.00 \%$ & 1 & $1.14 \%$ \\
\hline & Overall & 13 & $14.77 \%$ & 24 & $27.27 \%$ & 34 & $38.64 \%$ \\
\hline
\end{tabular}




\begin{tabular}{|c|c|c|c|c|c|c|c|}
\hline \multicolumn{8}{|c|}{$\begin{array}{l}\text { Appendix: Counts and Percentages of Position Advertisements for all } \\
\text { Keywords }\end{array}$} \\
\hline \multirow[t]{2}{*}{ Category } & \multirow[t]{2}{*}{ Keyword } & \multicolumn{2}{|c|}{ Required } & \multicolumn{2}{|c|}{$\begin{array}{c}\text { Required + } \\
\text { Preferred }\end{array}$} & \multicolumn{2}{|c|}{ Duties } \\
\hline & & \# ads & $\%$ ads & \# ads & $\%$ ads & \# ads & $\%$ ads \\
\hline \multirow[t]{19}{*}{$\begin{array}{l}\text { Cataloging } \\
\text { and } \\
\text { Processing }\end{array}$} & $\begin{array}{l}\text { Anglo-American } \\
\text { Cataloging Rules / } \\
\text { AACR }\end{array}$ & 13 & $14.77 \%$ & 14 & $15.91 \%$ & 3 & $3.41 \%$ \\
\hline & AMREMM & 1 & $1.14 \%$ & 1 & $1.14 \%$ & 1 & $1.14 \%$ \\
\hline & Cataloging & 25 & $28.41 \%$ & 39 & $44.32 \%$ & 42 & $47.73 \%$ \\
\hline & Classification(s) & 8 & $9.09 \%$ & 10 & $11.36 \%$ & 5 & $5.68 \%$ \\
\hline & Control & 6 & $6.82 \%$ & 7 & $7.95 \%$ & 8 & $9.09 \%$ \\
\hline & DACS & 4 & $4.55 \%$ & 10 & $11.36 \%$ & 1 & $1.14 \%$ \\
\hline & DCRM/DCRB & 6 & $6.82 \%$ & 7 & $7.95 \%$ & 0 & $0.00 \%$ \\
\hline & EAD & 3 & $3.41 \%$ & 14 & $15.91 \%$ & 2 & $2.27 \%$ \\
\hline & Finding aids & 3 & $3.41 \%$ & 5 & $5.68 \%$ & 13 & $14.77 \%$ \\
\hline & ILS & 1 & $1.14 \%$ & 1 & $1.14 \%$ & 0 & $0.00 \%$ \\
\hline & Innopac & 0 & $0.00 \%$ & 2 & $2.27 \%$ & 0 & $0.00 \%$ \\
\hline & $\mathrm{LCSH}$ & 7 & $7.95 \%$ & 7 & $7.95 \%$ & 2 & $2.27 \%$ \\
\hline & Metadata & 4 & $4.55 \%$ & 11 & $12.50 \%$ & 8 & $9.09 \%$ \\
\hline & Millennium & 2 & $2.27 \%$ & 4 & $4.55 \%$ & 0 & $0.00 \%$ \\
\hline & OCLC & 7 & $7.95 \%$ & 11 & $12.50 \%$ & 4 & $4.55 \%$ \\
\hline & Process/processing & 8 & $9.09 \%$ & 12 & $13.64 \%$ & 28 & $31.82 \%$ \\
\hline & RLIN & 1 & $1.14 \%$ & 3 & $3.41 \%$ & 1 & $1.14 \%$ \\
\hline & Voyager & 2 & $2.27 \%$ & 6 & $6.82 \%$ & 2 & $2.27 \%$ \\
\hline & Overall & 39 & $44.32 \%$ & 68 & $77.27 \%$ & 70 & $79.55 \%$ \\
\hline \multirow[t]{11}{*}{$\begin{array}{l}\text { Promotion and } \\
\text { Outreach }\end{array}$} & $\begin{array}{l}\text { Community/ } \\
\text { communities }\end{array}$ & 5 & $5.68 \%$ & 9 & $10.23 \%$ & 11 & $12.50 \%$ \\
\hline & Conference(s) & 0 & $0.00 \%$ & 0 & $0.00 \%$ & 1 & $1.14 \%$ \\
\hline & $\begin{array}{l}\text { Exhibition(s)/ } \\
\text { exhibit(s) }\end{array}$ & 2 & $2.27 \%$ & 7 & $7.95 \%$ & 36 & $40.91 \%$ \\
\hline & Faculty & 12 & $13.64 \%$ & 13 & $14.77 \%$ & 31 & $35.23 \%$ \\
\hline & Lectures & 0 & $0.00 \%$ & 0 & $0.00 \%$ & 7 & $7.95 \%$ \\
\hline & Organizations & 2 & $2.27 \%$ & 2 & $2.27 \%$ & 5 & $5.68 \%$ \\
\hline & Outreach & 3 & $3.41 \%$ & 3 & $3.41 \%$ & 22 & $25.00 \%$ \\
\hline & $\begin{array}{l}\text { Present/ } \\
\text { presentation }\end{array}$ & 6 & $6.82 \%$ & 6 & $6.82 \%$ & 13 & $14.77 \%$ \\
\hline & $\begin{array}{l}\text { Programs/ } \\
\text { programming }\end{array}$ & 4 & $4.55 \%$ & 4 & $4.55 \%$ & 41 & $46.59 \%$ \\
\hline & $\begin{array}{l}\text { Students/ } \\
\text { undergraduates }\end{array}$ & 9 & $10.23 \%$ & 10 & $11.36 \%$ & 24 & $27.27 \%$ \\
\hline & Overall & 22 & $25.00 \%$ & 30 & $34.09 \%$ & 72 & $81.82 \%$ \\
\hline
\end{tabular}




\begin{tabular}{|c|c|c|c|c|c|c|c|}
\hline \multicolumn{8}{|c|}{$\begin{array}{l}\text { Appendix: Counts and Percentages of Position Advertisements for all } \\
\text { Keywords }\end{array}$} \\
\hline \multirow[t]{2}{*}{ Category } & \multirow[t]{2}{*}{ Keyword } & \multicolumn{2}{|c|}{ Required } & \multicolumn{2}{|c|}{$\begin{array}{l}\text { Required + } \\
\text { Preferred }\end{array}$} & \multicolumn{2}{|c|}{ Duties } \\
\hline & & \# ads & $\%$ ads & \# ads & $\%$ ads & \# ads & $\%$ ads \\
\hline \multirow[t]{6}{*}{ Public Service } & $\begin{array}{l}\text { Clientele/ } \\
\text { customer(s)/ } \\
\text { patron(s) /user(s)/ } \\
\text { visitor(s) }\end{array}$ & 7 & $7.95 \%$ & 11 & $12.50 \%$ & 25 & $28.41 \%$ \\
\hline & Reference & 12 & $13.64 \%$ & 21 & $23.86 \%$ & 60 & $68.18 \%$ \\
\hline & Searching & 2 & $2.27 \%$ & 2 & $2.27 \%$ & 1 & $1.14 \%$ \\
\hline & Public Service(s) & 19 & $21.59 \%$ & 53 & $60.23 \%$ & 16 & $18.18 \%$ \\
\hline & Use & 17 & $19.32 \%$ & 20 & $22.73 \%$ & 27 & $30.68 \%$ \\
\hline & Overall & 40 & $45.45 \%$ & 77 & $87.50 \%$ & 72 & $81.82 \%$ \\
\hline \multirow{9}{*}{$\begin{array}{l}\text { Teaching and } \\
\text { Research }\end{array}$} & History & 28 & $31.82 \%$ & 38 & $43.18 \%$ & 19 & $21.59 \%$ \\
\hline & Instruction(al) & 10 & $11.36 \%$ & 18 & $20.45 \%$ & 32 & $36.36 \%$ \\
\hline & Methodology & 1 & $1.14 \%$ & 2 & $2.27 \%$ & 1 & $1.14 \%$ \\
\hline & Primary sources & 1 & $1.14 \%$ & 3 & $3.41 \%$ & 2 & $2.27 \%$ \\
\hline & $\begin{array}{l}\text { Publication(s)/ } \\
\text { publish }\end{array}$ & 10 & $11.36 \%$ & 16 & $18.18 \%$ & 7 & $7.95 \%$ \\
\hline & $\begin{array}{l}\text { Research activity/ } \\
\text { evidence/skills }\end{array}$ & 19 & $21.59 \%$ & 36 & $40.91 \%$ & 49 & $55.68 \%$ \\
\hline & $\begin{array}{l}\text { Scholar(s)/ } \\
\text { Scholarship }\end{array}$ & 10 & $11.36 \%$ & 15 & $17.05 \%$ & 13 & $14.77 \%$ \\
\hline & Teaching & 5 & $5.68 \%$ & 21 & $23.86 \%$ & 8 & $9.09 \%$ \\
\hline & Overall & 56 & $63.64 \%$ & 84 & $95.45 \%$ & 73 & $82.95 \%$ \\
\hline
\end{tabular}

